Prepared in cooperation with the U.S. Army Corps of Engineers, National Oceanic and Atmospheric Administration National Weather Service, Susquehanna River Basin Commission, and The Harrisburg Authority

\title{
Flood-Inundation Maps for the Susquehanna River near Harrisburg, Pennsylvania, 2013
}

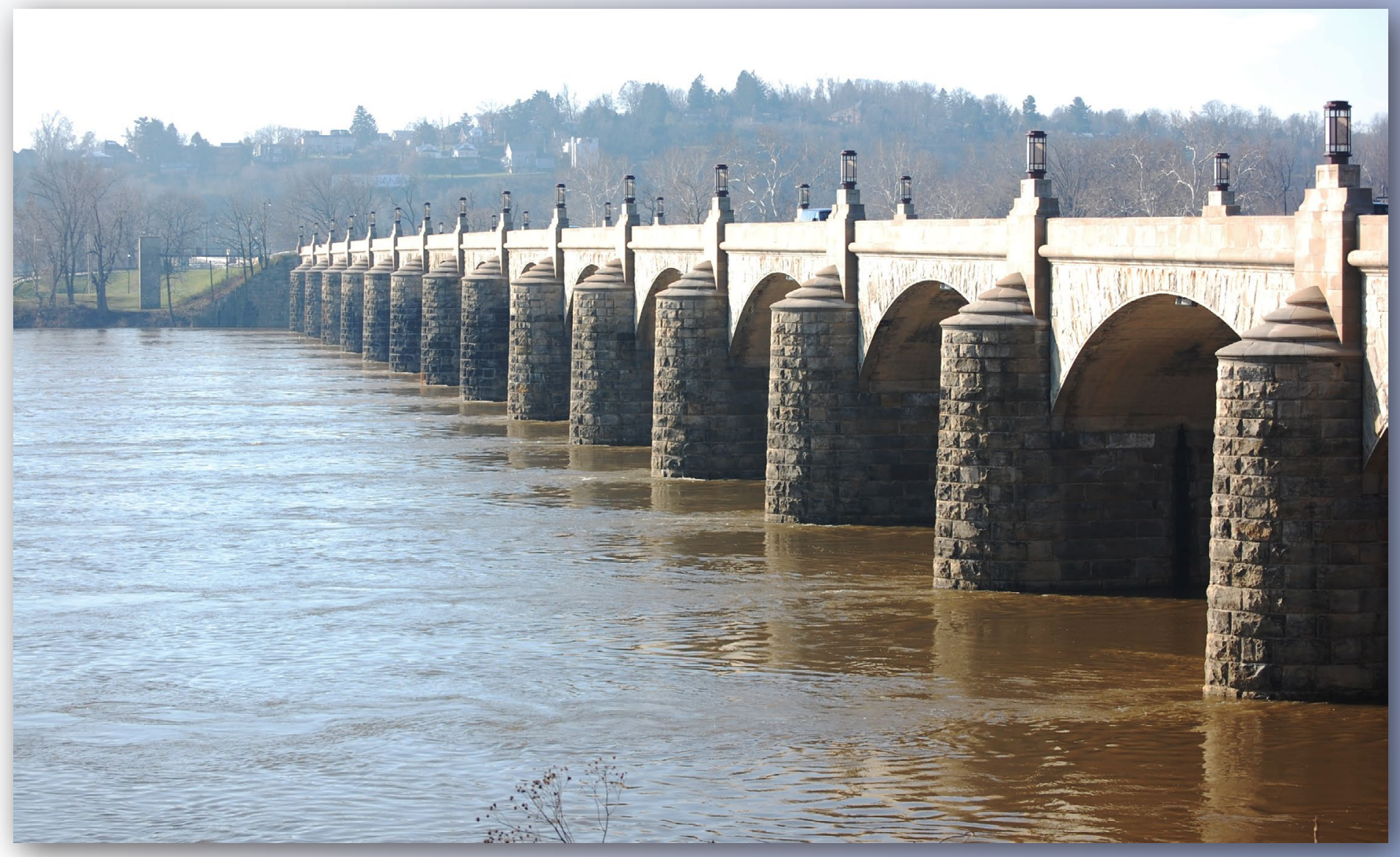

Scientific Investigations Report 2014-5046 
Cover. Market Street bridge over the Susquehanna River looking west toward City Island and U.S. Geological Survey streamgage 01570500, Susquehanna River at Harrisburg, Pennsylvania. Photograph by Scott A. Hoffman. 


\section{Flood-Inundation Maps for the Susquehanna River near Harrisburg, Pennsylvania, 2013}

By Mark A. Roland, Stacey M. Underwood, Craig M. Thomas, Jason F. Miller, Benjamin A. Pratt, Laurie G. Hogan, and Patricia A. Wnek

Prepared in cooperation with the U.S. Army Corps of Engineers, National Oceanic and Atmospheric Administration National Weather Service, Susquehanna River Basin Commission, and The Harrisburg Authority

Scientific Investigations Report 2014-5046 


\title{
U.S. Department of the Interior SALLY JEWELL, Secretary
}

\section{U.S. Geological Survey Suzette M. Kimball, Acting Director}

\author{
U.S. Geological Survey, Reston, Virginia: 2014
}

For more information on the USGS - the Federal source for science about the Earth, its natural and living resources, natural hazards, and the environment, visit http://www.usgs.gov or call 1-888-ASK-USGS.

For an overview of USGS information products, including maps, imagery, and publications, visit http://www.usgs.gov/pubprod

To order this and other USGS information products, visit http://store.usgs.gov

Any use of trade, firm, or product names is for descriptive purposes only and does not imply endorsement by the U.S. Government.

Although this information product, for the most part, is in the public domain, it also may contain copyrighted materials as noted in the text. Permission to reproduce copyrighted items must be secured from the copyright owner.

Suggested citation:

Roland, M.A., Underwood, S.M., Thomas, C.M., Miller, J.F, Pratt, B.A., Hogan, L.G., and Wnek, P.A., 2014, Floodinundation maps for the Susquehanna River near Harrisburg, Pennsylvania, 2013: U.S. Geological Survey Scientific Investigations Report 2014-5046, 17 p., http://dx.doi.org/10.3133/sir20145046

ISSN 2328-0328 (onlinel 


\section{Acknowledgments}

The authors wish to thank the many local, State, and Federal agencies that have cooperated in the funding for the operation and maintenance of the Pennsylvania streamgage network. Special thanks are given to the Harrisburg Authority and the City of Harrisburg for their cooperation in this study and to the Pennsylvania Silver Jackets organization for their support in this important effort. Thanks also go to Charles Ross of the National Weather Service Mid-Atlantic River Forecast Center and Moon Kim of the U.S. Geological Survey (USGS), Indiana Water Science Center, who provided valuable technical reviews of this report. Scott Hoffman, USGS, Pennsylvania Water Science Center, is thanked for his thorough review of the geographic information system inundation maps. 


\section{Contents}

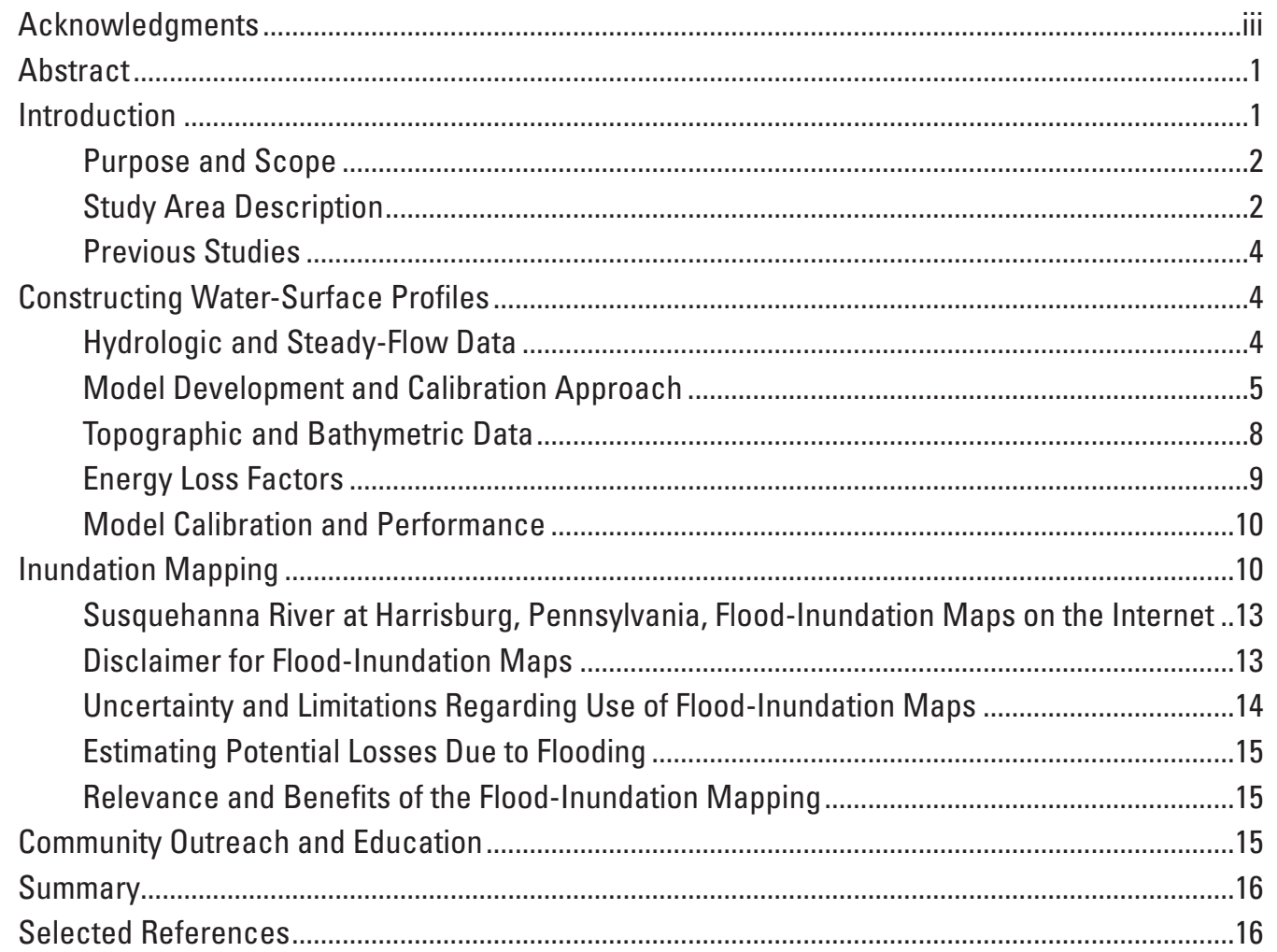

\section{Flood-inundation maps}

Estimated flood-inundation maps for the Susquehanna River near Harrisburg, Pennsylvania, referenced to U.S. Geological Survey streamgage 01573500, Susquehanna River at Harrisburg, Pennsylvania for stream stages 11-37 feet are available online from the U.S. Geological Survey Flood Inundation Mapping Science Web site at http://water.usgs.gov/osw/flood_inundation/. 


\section{Figures}

1. Map showing location of study reach along the Susquehanna River at Harrisburg, Pennsylvania, U.S. Geological Survey streamgage 01570500.

2. Graph showing river stages at storm sensor locations and U.S. Geological Survey streamgage 01570500 associated with flooding from Tropical Storm Lee, September 7-12, 2011, along the Susquehanna River near Harrisburg, Pennsylvania 6

3. Graph showing longitudinal water-surface profiles along the Susquehanna River near Harrisburg, Pennsylvania, associated with water-surface elevations during Tropical Storm Agnes in 1972 and Tropical Storm Lee in 2011

4. Screen capture showing the U.S. Geological Survey Flood Inundation Mapper web site depicting inundated areas within the study reach associated with a stage of 37 feet at the U.S. Geological Survey streamgage 01570500, Susquehanna River at Harrisburg, Pennsylvania...

\section{Tables}

1. Description of U.S. Geological Survey streamgage 01570500, Susquehanna River at Harrisburg, Pennsylvania.

2. Annual exceedance probability (AEP) peak-discharge estimates for selected locations on the Susquehanna River near Harrisburg, Pennsylvania

3. Top five flow events at U.S. Geological Survey streamgage 01570500 Susquehanna River at Harrisburg, Pennsylvania, and storm selection notes for the model calibration process

4. Structures included in HEC-RAS model for Susquehanna River near Harrisburg, Pennsylvania

5. Surveyed high-water mark elevations and hydraulic-model elevations from the flood of Tropical Storm Lee, September 2011, Susquehanna River near Harrisburg, Pennsylvania .

6. Surveyed high-water mark elevations and hydraulic-model elevations from the flood of June 1972, Tropical Storm Agnes, Susquehanna River near Harrisburg, Pennsylvania

7. Water-surface elevations at U.S. Geological Survey streamgage 01570500 and modeled water-surface elevations associated with annual maximum streamflows, Susquehanna River at Harrisburg, Pennsylvania, water years 1996-2010.

8. Water-surface elevations at U.S. Geological Survey streamgage 01570500 used as calibration targets and modeled water-surface elevations, Susquehanna River at Harrisburg, Pennsylvania. 


\section{Conversion Factors and Datums}

\begin{tabular}{|c|c|c|}
\hline Multiply & By & To obtain \\
\hline \multicolumn{3}{|c|}{ Length } \\
\hline foot $(\mathrm{ft})$ & 0.3048 & meter $(\mathrm{m})$ \\
\hline mile (mi) & 1.609 & kilometer (km) \\
\hline \multicolumn{3}{|c|}{ Area } \\
\hline square foot $\left(\mathrm{ft}^{2}\right)$ & 0.09290 & square meter $\left(\mathrm{m}^{2}\right)$ \\
\hline square mile $\left(\mathrm{mi}^{2}\right)$ & 2.590 & square kilometer $\left(\mathrm{km}^{2}\right)$ \\
\hline \multicolumn{3}{|c|}{ Flow rate } \\
\hline cubic foot per second $\left(\mathrm{ft}^{3} / \mathrm{s}\right)$ & 0.02832 & cubic meter per second $\left(\mathrm{m}^{3} / \mathrm{s}\right)$ \\
\hline
\end{tabular}

Vertical coordinate information is referenced to either (1) stage, the height above an arbitrary datum established at a streamgage, or (2) the height above North American Vertical Datum of 1988 (NAVD 88).

Horizontal coordinate information is referenced to the North American Datum of 1983 (NAD 83).

Elevation, as used in this report, refers to distance above the vertical datum.

Water year is defined as the 12-month period 0ctober 1, for any given year through September 30 , of the following year. The water year is designated by the calendar year in which it ends and which includes 9 of the 12 months. Thus, the year ending September 30, 1999, is called the "1999" water year. 


\title{
Flood-Inundation Maps for the Susquehanna River near Harrisburg, Pennsylvania, 2013
}

\author{
By Mark A. Roland, Stacey M. Underwood, Craig M. Thomas, Jason F. Miller, Benjamin A. Pratt, \\ Laurie G. Hogan, and Patricia A. Wnek
}

\section{Abstract}

A series of 28 digital flood-inundation maps was developed for an approximate 25-mile reach of the Susquehanna River in the vicinity of Harrisburg, Pennsylvania. The study was selected by the U.S. Army Corps of Engineers (USACE) national Silver Jackets program, which supports interagency teams at the state level to coordinate and collaborate on floodrisk management. This study to produce flood-inundation maps was the result of a collaborative effort between the USACE, National Weather Service (NWS), Susquehanna River Basin Commission (SRBC), The Harrisburg Authority, and the U.S. Geological Survey (USGS). These maps are accessible through Web-mapping applications associated with the NWS, SRBC, and USGS. The maps can be used in conjunction with the real-time stage data from the USGS streamgage 01570500, Susquehanna River at Harrisburg, Pa., and NWS flood-stage forecasts to help guide the general public in taking individual safety precautions and will provide local municipal officials with a tool to efficiently manage emergency flood operations and flood mitigation efforts.

The maps were developed using the USACE HEC-RAS and HEC-GeoRAS programs to compute water-surface profiles and to delineate estimated flood-inundation areas for selected stream stages. The maps show estimated flood-inundation areas overlaid on high-resolution, georeferenced, aerial photographs of the study area for stream stages at 1-foot intervals between 11 feet and 37 feet (which include NWS flood categories Action, Flood, Moderate, and Major) and the June 24, 1972, peak-of-record flood event at a stage of 33.27 feet at the Susquehanna River at Harrisburg, Pa., streamgage.

\section{Introduction}

The City of Harrisburg, Pennsylvania, is located along the east bank of the Susquehanna River and has an estimated population of 50,000 (U.S. Bureau of Census, 2010). The city and neighboring communities have historically experienced severe flooding. Major floods occurred in 1889, 1936, 1972, and most recently in 2011. Most of the flood damages in the study area have occurred along the Susquehanna River and several tributaries, including Paxton Creek, which flows directly through the city. Flood plains within and around the Harrisburg area are moderately to highly developed and contain a mix of residential and commercial structures.

Prior to this study, local officials have relied on several information sources to make decisions on how to best alert the public and mitigate flood damages. One source is the Federal Emergency Management Agency (FEMA) Flood Insurance Studies (FISs) that have been developed for communities in the study area (Federal Emergency Management Agency, 2009a, 2009b, 2009c, 2012). A second source of information is the U.S. Geological Survey (USGS) streamgage 01570500, Susquehanna River at Harrisburg, Pa., from which current or historical water levels (stage) can be obtained. A third source is the National Weather Service (NWS) forecast of peak stage at the USGS streamgage through the Advanced Hydrologic Prediction Service (AHPS) Web site. Although USGS current stage and NWS forecast stage information is particularly useful for residents in the immediate vicinity of a streamgage, this information is of limited use to residents farther upstream or downstream because the water-surface elevation is not constant along the entire stream channel. Also, FEMA and State emergency management mitigation teams or property owners typically lack information related to how deep the water is at locations other than near USGS streamgage or NWS floodforecast points.

This Harrisburg flood-inundation mapping study was selected by the U.S. Army Corps of Engineers (USACE) as one of the Silver Jackets Interagency Pilot Projects. The Silver Jackets Program is a national USACE program that establishes interagency teams at the state level to coordinate and collaborate on flood-risk management issues. The Pennsylvania Silver Jackets team comprises Federal, State, regional, and local agencies. This study to produce digital flood-inundation maps was the result of a collaborative effort between the USACE, NWS, Susquehanna River Basin Commission (SRBC), The Harrisburg Authority, and the USGS. 


\section{Purpose and Scope}

The purpose of this report is to describe the development of a series of estimated flood-inundation maps for the Susquehanna River near Harrisburg, Pa. The maps and other useful flood information are available from the following Web sites: USGS Flood Inundation Mapping Science (http://water. usgs.gov/osw/flood_inundation/), NWS AHPS (http://water. weather.gov), and the SRBC Susquehanna Inundation Map Viewer (SIMV) (http://maps.srbc.net/simv/). Internet users can select estimated inundation maps that correspond to (1) current stages at the USGS streamgage, (2) the NWS forecasted peak stage, or (3) other desired stream stages at 1-foot increments ranging from $11 \mathrm{feet}(\mathrm{ft})$ to $37 \mathrm{ft}$.

The scope of the study was limited to the Susquehanna River between the confluence with the Juniata River and the confluence with Swatara Creek as shown in figure 1. Tasks specific to development of the maps were (1) collection of water-level data throughout the study reach on the Susquehanna River; (2) collection of topographic data and geometric data (for structures/bridges) throughout the study reach; (3) determination of energy-loss factors (roughness coefficients) in the stream channel and flood plain, and steady-flow data; (4) computation of water-surface profiles using the USACE HEC-RAS computer program (U.S. Army Corps of Engineers, 2010); and (5) production of estimated flood-inundation maps at various stream stages by use of the USACE HEC-GeoRas computer program (U.S. Army Corps of Engineers, 2009) and a geographic information system (GIS).

The USGS conducted the data collection and the hydrologic data development tasks. The USACE developed the hydraulic model, developed the flood-inundation layers and depth grids, and managed the study. The SRBC and NWS conducted the outreach/education part of the project, and each of these agencies provided quality-control review.

Methods used are generally cited from previously published reports. If techniques varied substantially from previously documented methods because of local hydrologic conditions or availability of data, they are described in detail in this report. Maps were produced for water levels referenced to the water-surface elevation (stage) at the USGS streamgage 01570500 ranging from $11 \mathrm{ft}$ [associated discharge of
159,500 cubic feet per second $\left.\left(\mathrm{ft}^{3} / \mathrm{s}\right)\right]$, (defined as Action Stage by the NWS flood impact statement) to a stage of $37 \mathrm{ft}$ (associated discharge of $1,275,000 \mathrm{ft}^{3} / \mathrm{s}$ ), which is 125 percent of the maximum observed discharge at the streamgage. A flood-inundation map was also generated for a stage of $33.27 \mathrm{ft}$, which is the peak of record at this site (table 1).

\section{Study Area Description}

The Susquehanna River study reach is in south-central Pennsylvania near Harrisburg. The basin terrain is varied and lies within the Appalachian Plateau and Ridge and Valley Physiographic Provinces. The drainage area is approximately 23,150 square miles $\left(\mathrm{mi}^{2}\right)$ at the upstream end of the study reach, 24,100 $\mathrm{mi}^{2}$ at USGS streamgage 01570500 , and $24,940 \mathrm{mi}^{2}$ at the downstream extent of the study reach (fig. 1). The headwaters of the Susquehanna River originate at Lake Otsego in Cooperstown, New York, and the river flows generally southwestward approximately 380 miles (mi) before reaching the study area. Four major tributaries (Sherman Creek, Conodoguinet Creek, Yellow Breeches Creek, Swatara Creek) to the Susquehanna River join the main stem as it flows through the study reach; however, the drainage areas of the tributaries (244 $\mathrm{mi}^{2}, 508 \mathrm{mi}^{2}, 219 \mathrm{mi}^{2}, 571 \mathrm{mi}^{2}$, respectively) are relatively small compared to the overall drainage area of the Susquehanna River. The study reach is approximately $25 \mathrm{mi}$ long and has an average top-of-bank channel width of about 4,000 ft. The upstream limit of the reach is approximately $1,000 \mathrm{ft}$ downstream from the confluence with the Juniata River near the Borough of Duncannon, and the downstream limit is roughly $1,500 \mathrm{ft}$ downstream from the confluence with the Swatara Creek near the Borough of Middletown. In the vicinity of Harrisburg, most of the land contiguous to the study reach is classified as urban or developed with more than 7,000 parcels affected at the record peak flood stage associated with Tropical Storm Agnes in 1972. The main channel within the study reach has three interstate highway crossings; three lesser road crossings; and two railroad crossings, one of which is the world's longest stone arch bridge, the Rockville Bridge. There is a low-head dam (Dock Street dam) about $200 \mathrm{ft}$ upstream from the Interstate 83 bridge and a levee in the vicinity of the Harrisburg International airport.

Table 1. Description of U.S. Geological Survey streamgage 01570500, Susquehanna River at Harrisburg, Pennsylvania.

[ $\mathrm{mi}^{2}$, square miles; ft, feet; latitude and longitude are in degrees, minutes, and seconds]

\begin{tabular}{rcccccc}
\hline Station name & $\begin{array}{c}\text { Station } \\
\text { number }\end{array}$ & $\begin{array}{c}\text { Drainage area } \\
\left(\mathbf{m i}^{2}\right)\end{array}$ & Latitude & Longitude & Period of record & $\begin{array}{c}\text { Maximum documented stage } \\
\text { at gage } \mathbf{~}^{\mathbf{( f t}} \text { ) and date }\end{array}$ \\
\hline $\begin{array}{r}\text { Susquehanna River } \\
\text { at Harrisburg, Pa. }\end{array}$ & 01570500 & 24,100 & $40^{\circ} 15^{\prime} 17^{\prime \prime}$ & $76^{\circ} 53^{\prime} 11^{\prime \prime}$ & $\begin{array}{c}\text { October } 1890 \text { to } \\
\text { current }(2013)\end{array}$ & $32.57 \mathrm{ft}^{1} \mathrm{June}^{24,1972}$ \\
\hline
\end{tabular}

${ }^{1} \mathrm{~A}$ stage of $33.27 \mathrm{ft}$ was documented from a high-water mark at the current (2013) location of the streamgage on City Island, which is approximately 3,000 ft upstream from its location in 1972. 


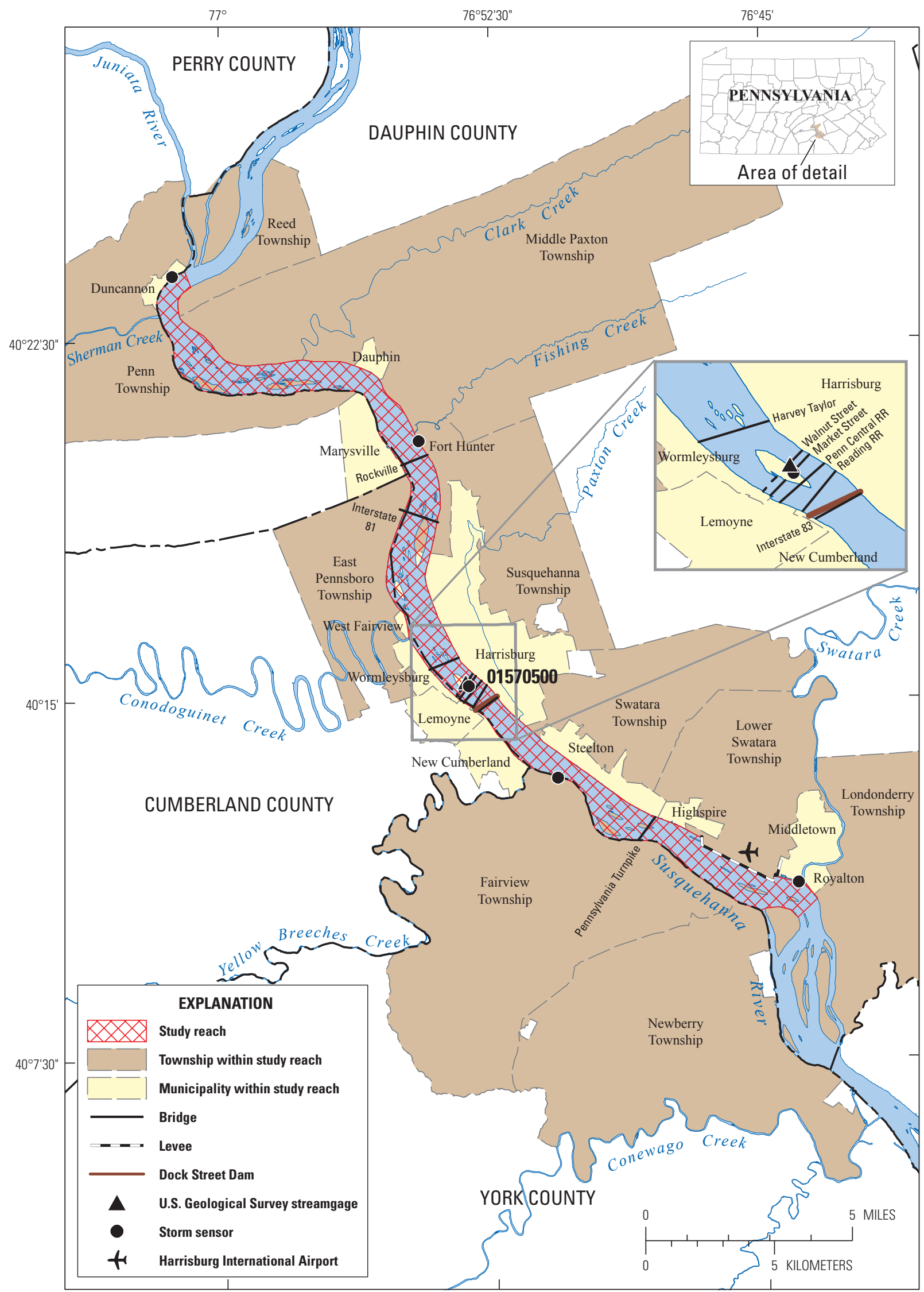

Figure 1. Location of study reach along the Susquehanna River at Harrisburg, Pennsylvania, U.S. Geological Survey streamgage 01570500. 


\section{Previous Studies}

A report titled "Floods of June 1972 in the Harrisburg Area, Pennsylvania" (Page and Shaw, 1973) documents the approximate area inundated by the flood resulting from Tropical Storm Agnes in June 1972. The report was published as a hydrologic atlas, and it presents information on the frequency, depth, and extent of flooding along a 20-mi reach of the Susquehanna River from Marysville, Pa., to Falmouth, Pa., including the Harrisburg area. The report was prepared by the USGS, in cooperation with the Pennsylvania Department of Environmental Resources, the SRBC, and the USACE. Information included in that report, specifically the flood profiles from 1972 and 1936 were used to help calibrate and verify the hydraulic model used in this study.

The current FIS for Dauphin County, Pa., (Federal Emergency Management Agency, 2012) provided information on the annual exceedance probability discharge estimates, water-surface profiles, and associated flood plain maps for the Susquehanna River within the study area. Estimates of the peak discharges for the 10-, 2-, 1-, and 0.2-percent annual exceedance probability floods along the Susquehanna River are listed in table 2 for the study reach.

\section{Constructing Water-Surface Profiles}

The water-surface profiles used to produce the Susquehanna River flood-inundation maps in this study were computed using HEC-RAS, version 4.1.0. HEC-RAS is a one-dimensional step-backwater model for simulation of water-surface profiles with steady-state (gradually varied) or unsteady-state flow computation options. The HEC-RAS analysis for this study was done using the steady-state flow computation option.

HEC-GeoRAS was used in the development of the HECRAS model, allowing the model to be geo-referenced. The horizontal coordinates of the HEC-RAS model are referenced to Pennsylvania State Plane Feet, North American Datum of 1983 (NAD 83), with all vertical elevations referenced to North American Vertical Datum of 1988 (NAVD 88). HEC-GeoRAS was used to identify the stream centerline, bank station locations, flow paths, and obstruction locations throughout the study reach. The placement of cross sections at logical locations throughout the study reach also was performed utilizing HEC-GeoRAS - upstream and downstream from bridge embankments, at existing or previous USGS streamgages, at sites where stream-channel surveys had been performed, near locations of high-water marks from historical storms, or locations of existing lettered cross sections from the effective FEMA FIS. Cross sections and bridges are identified by river mile.

The calibration of the HEC-RAS hydraulic model included three steps. The first step involved calibrating the model to large, infrequent storms that produced historically high discharges for which data are available (for example, stage, discharge, and high-water marks). The second step involved verification of the calibrated model with data from several other storms of less magnitude and comparatively less discharge. The third step was to evaluate the calibrated and verified hydraulic model relative to the most recent stagedischarge rating curve in use at USGS streamgage 01570500, Susquehanna River at Harrisburg, Pa.

\section{Hydrologic and Steady-Flow Data}

The study area hydrologic network (fig. 1) consisted of one USGS streamgage (01570500) and five submersible pressure transducers (also known as storm sensors) with internal logging capability that were temporarily deployed in the study reach to record water level and (or) barometric pressure during flooding that occurred September 7-12, 2011. The streamgage was already in operation, and the pressure transducers were deployed specifically for this study to collect data to be used for model calibration. Water level (stage) was measured continuously (5-minute intervals for the pressure transducers and 30-minute intervals for the streamgage) at all of the sites, and continuous records of streamflow were computed at the streamgage. USGS streamgage 01570500 is the only continuous recording streamgage within the study reach and has been in operation at its current location since August 1975. During 1928-74, the streamgage was located approximately 3,000 ft downstream along the left bank near Nagle Street (just upstream from the Dock Street dam). Prior to 1928 , there was a non-recording streamgage at the Walnut Street bridge, approximately $600 \mathrm{ft}$ upstream from the current

Table 2. Annual exceedance probability (AEP) peak-discharge estimates for selected locations on the Susquehanna River near Harrisburg, Pennsylvania.

[Data are from Federal Emergency Management Agency, 2012. $\mathrm{mi}^{2}$, square miles; $\mathrm{ft}^{3} / \mathrm{s}$, cubic feet per second]

\begin{tabular}{|c|c|c|c|c|c|}
\hline \multirow{2}{*}{ Location on Susquehanna River } & \multirow{2}{*}{$\begin{array}{l}\text { Drainage area } \\
\qquad\left(\mathrm{mi}^{2}\right)\end{array}$} & \multicolumn{4}{|c|}{ Peak-discharge estimates $\left(\mathrm{ft}^{3} / \mathrm{s}\right)$} \\
\hline & & 10-percent AEP & 2-percent AEP & 1-percent AEP & 0.2-percent AEP \\
\hline Approximately 250 feet upstream from Interstate 76 & 24,100 & 410,000 & 600,000 & 700,000 & $1,100,000$ \\
\hline
\end{tabular}


location. The current streamgage (01570500) is equipped with satellite radio transmitters that allow data to be transmitted at regular intervals on the internet within an hour of collection. All water-surface elevations are referenced to North American Vertical Datum of 1988 (NAVD 88).

Four storm sensors were deployed at locations that allowed relative ease of access to the river's edge and were spaced at approximately equidistant locations throughout the reach near the communities of Duncannon, Fort Hunter, New Cumberland, and Middletown, in upstream to downstream order. A fifth sensor was deployed at the streamgage (approximately midpoint in study reach) at an elevation high enough that it would not become submerged. The purpose of this sensor was to continuously record barometric pressure, which was used to correct the absolute pressure recordings of the four submerged sensors. The location of the sensors is shown in figure 1.

The sensors were deployed on September 7, 2011, during Tropical Storm Lee, when the river was at an approximate stage of 12 to $13 \mathrm{ft}$ (1 to $2 \mathrm{ft}$ above the NWS flood category Action Stage of $11 \mathrm{ft}$ at USGS streamgage 01570500) and was still rising. On September 12-13, 2011, the sensors were retrieved after the flood water had receded. A peak gage height of $25.17 \mathrm{ft}$ was recorded at the streamgage on September 9, 2011. The stage data recorded by each of the four sensors was post-processed using the barometric pressure data recorded from the sensor at the streamgage and converted to an elevation by means of a surveyed reference point. This allowed the data from the four sensors, in addition to the streamgage data, to be considered in terms of water-surface elevations, which was ultimately used for model calibration purposes. Stage hydrographs of the data obtained from the four storm sensors as well as USGS streamgage 01570500 data recorded during September 7-12, 2011, are shown in figure 2.

Using the continuously recorded water-surface data, longitudinal profiles were generated, ranging from $12.89 \mathrm{ft}$ to the peak recorded gage height of $25.17 \mathrm{ft}$, in approximate $2-\mathrm{ft}$ increments. The shapes of the profiles are almost identical, essentially stacked on top of each other as the water surface got higher at each gaged location (fig. 3).

Longitudinal water-surface profiles obtained from highwater marks along the Susquehanna River were documented following floods in 1936 and 1972 (Page and Shaw, 1973) and were used for model calibration. For comparison, the June 1972 profile data were incorporated into a spreadsheet that was used to generate the longitudinal water-surface profiles associated with the September 7-12, 2011, flooding. Although the peak profile for the September 2011 event was associated with a maximum recorded stage of $25.17 \mathrm{ft}$ at the streamgage, the overall shape compared favorably with the June 1972 (Tropical Storm Agnes) flood profile, which had an associated peak stage of $33.27 \mathrm{ft}$ (fig. 3). This finding engendered additional confidence in the data being used to calibrate the model.

Steady-flow data consist of flow regime, boundary conditions (water-surface elevation associated with a discharge measurement, critical depth, normal depth, or streamgage rating-curve value), and peak discharge information. The steady-flow data for the study reach were obtained from field measurements of streamflow observed periodically (over a range of stages) at the USGS streamgage 01570500, Susquehanna River at Harrisburg, Pa. These measured discharge values along with known stages were used to develop the stage-discharge relation (streamgage rating-curve). The current rating curve in effect for USGS streamgage 01570500 is rating number 19.0 .

\section{Model Development and Calibration Approach}

A HEC-RAS model was developed as a tool to estimate water-surface elevations at cross-sectional locations within the approximate 25 -mi study reach that would be expected when the USGS streamgage 01570500, Susquehanna River at Harrisburg, Pa., is at specific flows and stages. The hydraulic model was calibrated by adjusting geometric input variables to generate model results that matched observed data, such as high-water marks, stage, and flow associated with storm events.

Historical observed data (peak stage and flow) from USGS streamgage 01570500 were used for the calibration process. Peak stage and flow data from the highest flow events associated with this streamgage were reviewed for the selection of three storms to include in the calibration process, as either a primary or a secondary storm (table 3). High-water marks for Tropical Storm Agnes (June 1972), the March 1936 storm, and Tropical Storm Lee (September 2011) and storm sensor data collected during Tropical Storm Lee also were used for calibration.

Tropical Storm Lee was considered a primary storm event and was given the highest priority for hydraulic model calibration because it is the most recent of the storms considered and storm sensor and streamgage data (stage and flow) are available. Tropical Storm Agnes also was considered a primary storm event and was given next highest priority for model calibration because the storm produced the highest flow of record at USGS streamgage 01570500 and a measurement was made during the storm. The third priority for model calibration was matching post-storm high-water marks for Tropical Storms Lee and Agnes. The lowest priority for model calibration was matching post-storm high-water marks and streamgage data for the March 1936 flood because of the age of the data and the amount of change that had occurred in the channel and flood plain in the 75 years since that storm.

For all calibration, verification, and existing-conditions model runs, all cross sections within the model were assigned the same flow value, which was the value for USGS streamgage 01570500, Susquehanna River at Harrisburg, Pa. All tributaries entering the Susquehanna River within the study reach have drainage areas that are much smaller than the Susquehanna River drainage area, and the peak flows of these tributaries would occur well before the peak flow of the Susquehanna River. Therefore, a uniform flow value for the 


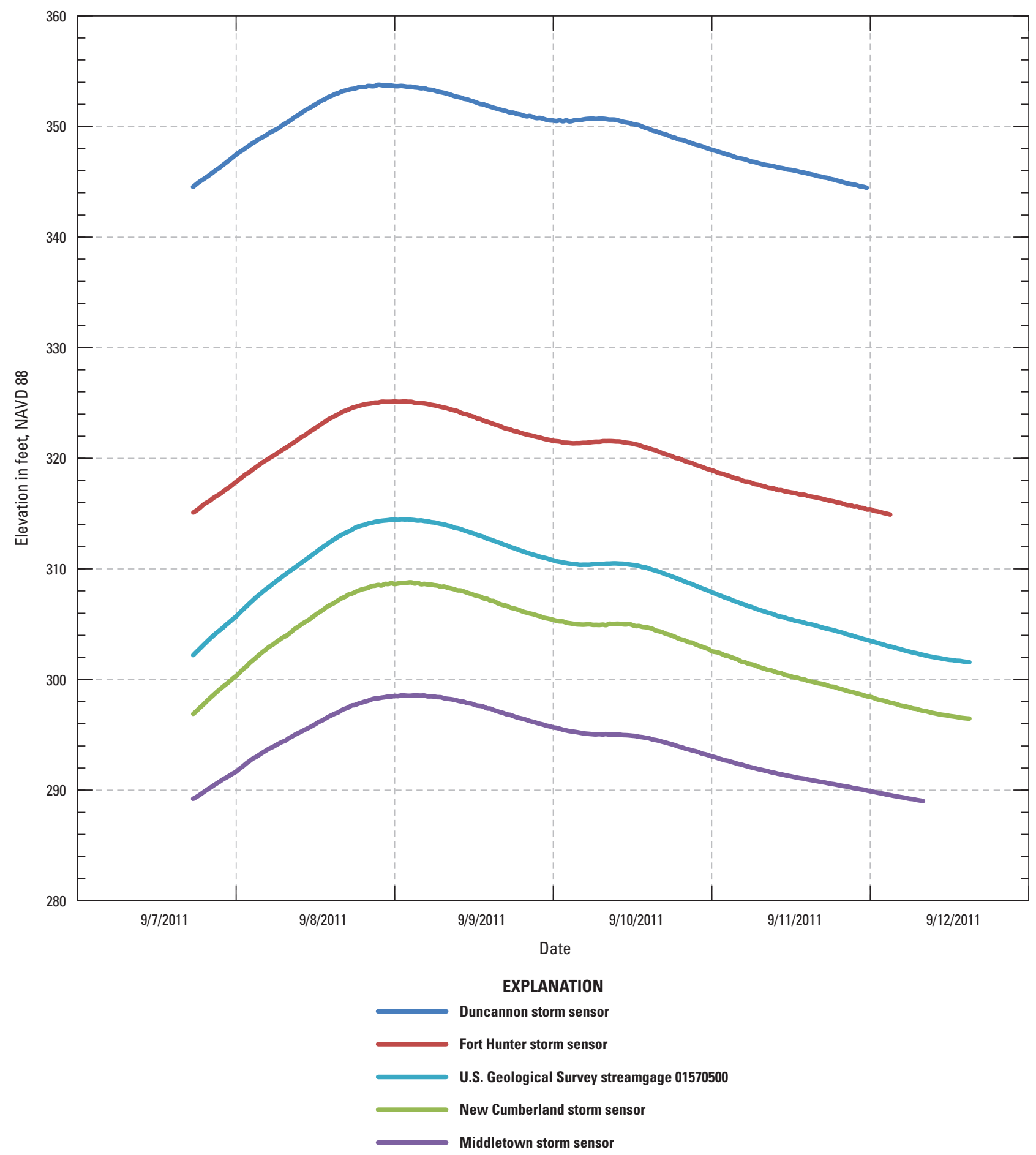

Figure 2. River stages at storm sensor locations and U.S. Geological Survey streamgage 01570500 associated with flooding from Tropical Storm Lee, September 7-12, 2011, along the Susquehanna River near Harrisburg, Pennsylvania. 


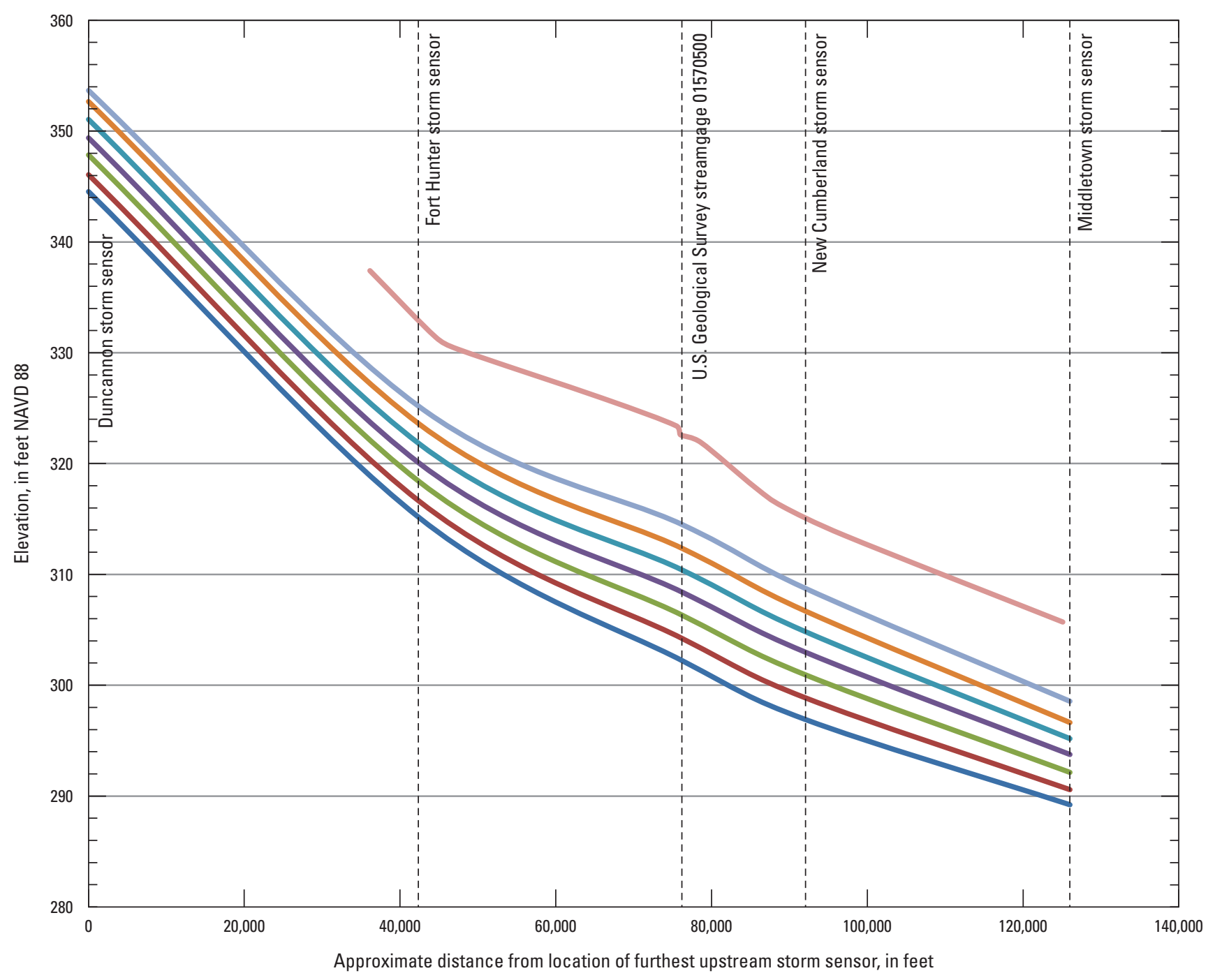

\section{EXPLANATION}

Gage height at U.S. Geological Survey streamgage 01570500 , in feet

Tropical Storm Agnes, 1972

\subsection{7}

Tropical Storm Lee, 2011

25.17

23.02

21.07

19.07
16.99

14.89

Figure 3. Longitudinal water-surface profiles along the Susquehanna River near Harrisburg, Pennsylvania, associated with watersurface elevations during Tropical Storm Agnes in 1972 and Tropical Storm Lee in 2011. 
Table 3. Top five flow events at U.S. Geological Survey streamgage 01570500 Susquehanna River at Harrisburg, Pennsylvania, and storm selection notes for the model calibration process.

[n/a, not applicable; $\mathrm{ft}^{3} / \mathrm{s}$, cubic feet per second]

\begin{tabular}{|c|c|c|c|c|c|c|}
\hline $\begin{array}{l}\text { Storm } \\
\text { rank }\end{array}$ & $\begin{array}{l}\text { Storm } \\
\text { date }\end{array}$ & $\begin{array}{l}\text { Storm } \\
\text { name }\end{array}$ & $\begin{array}{c}\text { Peak flow } \\
\left(\mathrm{ft}^{3} / \mathrm{s}\right)\end{array}$ & $\begin{array}{c}\text { Peak stage } \\
\text { (feet) }\end{array}$ & Calibration & Notes \\
\hline 1 & $6 / 24 / 1972$ & $\begin{array}{l}\text { Tropical } \\
\text { Storm } \\
\text { Agnes }\end{array}$ & $1,020,000$ & 32.57 & Primary & $\begin{array}{l}\text { Used as primary calibration storm because it had the highest flow on } \\
\text { record and high-water mark data are available from the hydrologic } \\
\text { atlas (Page and Shaw, 1973). }\end{array}$ \\
\hline 2 & $3 / 19 / 1936$ & $\mathrm{n} / \mathrm{a}$ & 740,000 & 29.23 & Secondary & $\begin{array}{l}\text { Used as a verification storm because the magnitude of the event and } \\
\text { high-water mark data are available from the hydrologic atlas (Page } \\
\text { and Shaw, 1973). Not used as a primary calibration storm because } \\
\text { the quality of the high-water marks is low and substantial changes } \\
\text { to the river and flood plain may have occurred since the storm. }\end{array}$ \\
\hline 3 & $6 / 2 / 1889$ & $\mathrm{n} / \mathrm{a}$ & 654,000 & 26.80 & None & $\begin{array}{l}\text { Not used for calibration as high-water marks throughout the study } \\
\text { reach are not available and substantial changes to the river and flood } \\
\text { plain may have occurred since the storm. }\end{array}$ \\
\hline 4 & $5 / 22 / 1894$ & $\mathrm{n} / \mathrm{a}$ & 613,000 & 25.70 & None & $\begin{array}{l}\text { Not used for calibration as high-water marks throughout the study } \\
\text { reach are not available and substantial changes to the river and flood } \\
\text { plain may have occurred since the storm. }\end{array}$ \\
\hline
\end{tabular}

entire study reach was deemed appropriate. A rating curve was used as the downstream boundary condition for the HECRAS model. This rating curve was developed using a variety of sources, including the rating curve for USGS streamgage 01570500 (rating 19.0), storm sensor data from Tropical Storm Lee, and high-water marks from the 1936 storm and Tropical Storm Agnes. The downstream boundary for the model is located near Middletown, Pa., upstream from the confluence with the Swatara Creek tributary. For mapping purposes in the vicinity of the confluence, the modeled water-surface elevations were carried downstream from the tributary.

\section{Topographic and Bathymetric Data}

The HEC-RAS geometry was prepared with great detail using the high-resolution digital elevation model (DEM), bridge plans and bridge measurements/photographs, aerial photography, and field visits. A total of 123 cross sections were used in the HEC-RAS model. Digital elevation data for the parts of all cross sections that were above the water surface at the time of the study were obtained from a DEM used by the PAMAP Program, which is managed by the Pennsylvania Department of Conservation and Natural Resources, Bureau of Topographic and Geologic Survey (PAMAP, 2006). This dataset consists of output from a raster digital elevation model with a horizontal ground resolution of $3.2 \mathrm{ft}$. The horizontal accuracy standard follows the National Standard for Spatial Data Accuracy (NSSDA)-1998 standard. The maximum permissible root-mean-square error (RMSE) for 95 percent of the horizontal check points for the mapping product is $5 \mathrm{ft}$ or less (PAMAP, 2006). The model was constructed from PAMAP Light Detection and Ranging (lidar) elevation points measured during 2006-08. The vertical accuracy meets the requirements of NSSDA at the 95-percent confidence interval (1.96 × RMSE) (PAMAP, 2006). Additional information about the basis for these standards can be found in "Partnered Guidelines for the Development of Advanced Hydrologic Prediction Service Flood Inundation Mapping" by National Oceanographic and Atmospheric Administration (NOAA), (2011).

Channel cross sections within the HEC-RAS model were developed using various sources. These sources include bathymetry data collected by the USGS from various projects and discharge measurements, Pennsylvania Department of Transportation (PennDOT) bridge plans, and the HEC-2 model from the appropriate FEMA FIS. For intermediate cross sections between surveyed channel sections, the channel geometry was interpolated using a GIS routine.

Various manmade drainage structures (bridges, levees, and dams) in and along the river affect or have the potential to affect water-surface elevations during floods. To properly account for these features in the model, structural dimensions for 9 bridges, 1 in-channel dam, and 1 levee system were acquired from various sources and input into the HEC-RAS model. The structures and the associated data sources are listed in table 4.

For the Walnut Street bridge at river mile 69.40, three of the eight spans on the west side of City Island collapsed during a flood in 1996 and were never repaired. The three spans 
Table 4. Structures included in HEC-RAS model for Susquehanna River near Harrisburg, Pennsylvania.

[PA, Pennsylvania; USGS, U.S. Geological Survey; PennDOT, Pennsylvania Department of Transportation; FEMA, Flood Emergency Management Agency]

\begin{tabular}{|c|c|c|c|}
\hline River mile & Structure name & Description & Data source \\
\hline 75.15 & Rockville Bridge & Stone arch bridge & $\begin{array}{l}\text { USGS field reconnaissance and FEMA HEC- } 2 \\
\text { model }\end{array}$ \\
\hline 70.03 & Harvey Taylor Bridge & Elevated, arched bridge & PennDOT Plans S-1647 (dated 1950) \\
\hline 69.31 & Market Street Bridge & Stone arch and concrete bridge & $\begin{array}{l}\text { PennDOT Plans S-26860 (dated 2007), S-5635 } \\
\text { (dated 1962) and FEMA HEC-2 model }\end{array}$ \\
\hline 69.14 & Penn Central Railroad & Stone arch bridge & $\begin{array}{l}\text { USGS field reconnaissance and FEMA HEC-2 } \\
\text { model }\end{array}$ \\
\hline 68.65 & Interstate Highway 83 & Concrete bridge & $\begin{array}{l}\text { PennDOT Plans S-12130 (dated 1979) and } \\
\text { USGS field reconnaissance }\end{array}$ \\
\hline 63.75 & Interstate Highway 76 (PA Turnpike) & Concrete bridge & PennDOT Plans A-00118748 (dated 2007) \\
\hline $62.41-60.49$ & Airport Levee System & $\begin{array}{c}\text { Privately owned levee at airport built in } \\
1956 \text { at a top elevation of } 310.3 \text { feet }\end{array}$ & $\begin{array}{l}\text { Harrisburg International Airport engineer } \\
\text { (March 2012) }\end{array}$ \\
\hline
\end{tabular}

were included in the hydraulic modeling for Tropical Storm Agnes (1972 peak of record flood event) but were removed for Tropical Storm Lee and all existing-conditions model runs. Model results show, however, that the removal of the spans from the model had no effect on water-surface elevations.

The Harrisburg International Airport privately owned levee system, located between river miles 62.41 and 60.49 , experienced issues during Tropical Storm Agnes that caused flooding behind the levee. A closure structure was not properly engaged, causing water to enter the airport property. Therefore, the levee was removed from the hydraulic model for Tropical Storm Agnes to allow floodwaters to inundate the airport. The removal of the levee, however, had no effect on water-surface elevations.

\section{Energy Loss Factors}

Manning's values, contraction/expansion coefficients, bridge hydraulic properties, ineffective flow areas, and other hydraulic variables were assigned on the basis of field conditions. Field observations and high-resolution aerial photographs were used to select initial (pre-calibration) Manning's roughness coefficients (" $n$ " values) for energy (friction) loss calculations. Results of initial runs of the model using only horizontally varying $n$ values compared well with the high-water marks and data associated with the streamgage and storm sensors deployed during Tropical Storm Lee. However, once flow and high-water mark data from Tropical Storm Agnes were entered into the model, the model results indicated higher water-surface elevations than those associated with the observed high-water marks. The flow during Tropical Storm Agnes was almost double the flow during Tropical Storm Lee within the study reach. It was determined that, as a result of the presence of numerous vegetated islands within the main channel (which can cause reduced conveyance), the friction loss would be reduced once flow had increased to a point where water-surface elevations exceeded tree lines and other natural obstructions. To account for this physical occurrence, vertical variations in $n$ values were input into the model at most cross sections. By varying $n$ values vertically, the recomputed water-surface elevations associated with the model compared favorably to the observed high-water marks, streamgage data, and storm sensor data for Tropical Storm Lee and high-water marks for Tropical Storm Agnes. The final Manning's $n$ values used ranged from 0.020 to 0.044 for the main channel, 0.080 (low flow) to 0.025 (high flow) for islands within the main channel, and 0.013 to 0.120 for the overbank areas modeled in this analysis. The $n$ value of 0.013 in the overbank areas represents roadways and paved areas, and the $0.120 n$ value represents dense stands of mature trees or areas containing extensive buildings. 


\section{Model Calibration and Performance}

The hydraulic model was calibrated to the storm sensor data collected in 2011 during Tropical Storm Lee and to the streamgage and high-water marks from the floods in 1972 (Tropical Storm Agnes) and 2011. Verification of the model was conducted by analyzing peak storm events from 1936 and 1996 to 2010. Ultimately, the hydraulic model was evaluated on the basis of the most current stage-discharge relation (rating 19.0) at the USGS streamgage 01570500, Susquehanna River at Harrisburg, Pa. The estimated peak discharge for the Tropical Storm Lee flood was 590,000 ft3 $/ \mathrm{s}$ at an estimated stage of about $25.17 \mathrm{ft}$ at the streamgage. The measured peak discharges (and stages) for Tropical Storm Agnes and the $1936 \mathrm{floods}$ were $1,020,000 \mathrm{ft}^{3} / \mathrm{s}(32.57 \mathrm{ft})$ and $740,000 \mathrm{ft}^{3} / \mathrm{s}$ (29.23 ft), respectively. (These discharges/stages are associated with USGS streamgage 01570500 when it was located approximately 3,000 ft downstream from its current location on City Island.) The model was not sensitive (modeled watersurface elevations did not vary significantly) to factors such as contraction/expansion coefficients, overbank roughness values, or pier debris and momentum coefficients. Results of initial runs of the model indicate that it was most sensitive to channel roughness (Manning's $n$ ) value adjustments. Consequently, channel roughness values were adjusted to enable computed water-surface elevations to best match observed data from storm sensor, high-water mark, and streamgage data on the basis of the calibration priorities.

Water-surface elevation data were collected at five locations (USGS streamgage 01570500 and four storm sensors) throughout the study reach (fig. 1) during Tropical Storm Lee. The HEC-RAS model was generally calibrated to within $\pm 0.2 \mathrm{ft}$ of these data. In addition to the continuously recorded data obtained during Tropical Storm Lee, high-water mark elevations were obtained by The Harrisburg Authority. Surveyed high-water mark elevations, modeled water-surface elevations, and the difference between the two, which ranged from $-0.70 \mathrm{ft}$ to $+1.7 \mathrm{ft}$ (with an average difference of $+0.26 \mathrm{ft}$ ) throughout the study reach, are listed in table 5, along with the river mile. It is worth noting that the relative quality of the high-water marks (for instance, poor, fair, good, excellent) was not documented. This information is sometimes captured during the field survey in an attempt to provide insight as to how well a post-flood high-water mark represents the actual peak water-surface elevation at the time of flooding. Although subjective, this qualitative information can be useful during the model calibration and evaluation process to the extent that a higher degree of confidence would be associated with the surveyed elevation of a high-water mark categorized as excellent, as opposed to a high-water mark being considered poor.

Tropical Storm Agnes occurred in 1972 and is the largest flood on record for the Susquehanna River at Harrisburg, Pa., streamgage to date. Historical high-water mark information was obtained from a report documenting the flooding in the Harrisburg area (Page and Shaw, 1973), as well as from PennDOT bridge plans and USACE surface-water profiles
(U.S. Army Corps of Engineers, 1974). The relative quality of the high-water marks was not documented. Differences between measured and simulated water levels for the flood of Tropical Storm Agnes, June 1972, ranged from -1.5 to $+0.7 \mathrm{ft}$ (with an average difference of $-0.29 \mathrm{ft}$ ) throughout the study reach (table 6). These differences seemed reasonable given the inherent uncertainty associated with high-water mark retrieval and documentation.

Peak stage (converted to NAVD 88 elevation) at USGS streamgage 01570500 and modeled water-surface elevations associated with annual maximum streamflows for water years 1996-2010 were evaluated to verify the model's accuracy for smaller, more frequent storms in comparison to a larger storm event such as Tropical Storm Agnes that occurred in 1972. The results are presented in table 7 .

The modeled values are within $\pm 0.2 \mathrm{ft}$ of the observed values for all 15 storms evaluated. The results of the verification analysis confirm the model's ability to accurately compute water-surface elevations for small, more frequent storms.

Using the calibrated and verified hydraulic model, water-surface profiles were developed for a total of 27 stages at 1-ft increments from $11 \mathrm{ft}$ (NWS flood category Action Stage) to $37 \mathrm{ft}$, which is the corresponding stage associated with 125-percent of the peak flow of record at the USGS streamgage 01570500, Susquehanna River at Harrisburg, Pa. A water-surface profile was also developed for Tropical Storm Agnes, which was the peak-of-record flood event for this site at a stage of $33.27 \mathrm{ft}$. Discharges corresponding to the various stages were obtained from the most current stage-discharge relation (rating 19.0) at the USGS streamgage 01570500 and entered into the model. Stage and discharge data associated with the rating of 19.0 and the comparative model results are presented in table 8 .

\section{Inundation Mapping}

Flood-inundation maps (FIMs) were created for the USGS streamgage 01570500, Susquehanna River at Harrisburg, Pa., which is a designated NWS flood-forecast point. The maps were created in a GIS by combining the water-surface elevation profiles and DEM data for the study area. The DEM data were derived from 3.2-ft horizontal resolution lidar data obtained from the PAMAP Program (PAMAP, 2006). Estimated flood-inundation boundaries for each simulated profile were developed with HEC-GeoRAS software. HECGeoRAS is a set of procedures, tools, and utilities for processing geospatial data in ArcGIS (Esri, 2013) by using a graphical user interface (Whitehead and Ostheimer, 2009). The interface allows the preparation of geometric data for import into HECRAS and processes simulation results exported from HECRAS (U.S. Army Corps of Engineers, 2010).

The HEC-RAS output file contained 28 modeled watersurface profiles from stage $11 \mathrm{ft}$ through stage $37 \mathrm{ft}$ as measured at USGS streamgage 01570500 and stage of $33.27 \mathrm{ft}$, 
Table 5. Surveyed high-water mark elevations and hydraulicmodel elevations from the flood of Tropical Storm Lee, September 2011, Susquehanna River near Harrisburg, Pennsylvania.

[NAVD 88, North American Vertical Datum of 1988; ft, feet]

\begin{tabular}{|cccc}
\hline $\begin{array}{c}\text { River } \\
\text { mile }\end{array}$ & $\begin{array}{c}\text { High-water mark } \\
\text { elevation } \\
\text { (ft above NAVD 88) }\end{array}$ & $\begin{array}{c}\text { Modeled water- } \\
\text { surface elevation } \\
\text { (ft above NAVD 88) }\end{array}$ & $\begin{array}{c}\text { Elevation } \\
\text { difference } \\
\text { (ft) }\end{array}$ \\
\hline 75.82 & 325.9 & 326.1 & +0.2 \\
\hline 74.99 & 322.0 & 323.4 & +1.4 \\
\hline 72.84 & 319.3 & 318.9 & -0.4 \\
\hline 69.95 & 316.8 & 316.3 & -0.5 \\
\hline 69.03 & 314.9 & 314.2 & -0.7 \\
\hline 66.43 & 308.8 & & \\
\hline & & 308.8 & \\
\hline $\begin{array}{l}1 \text { Approximate location of U.S. Geological Survey streamgage } 01570500 \\
(1975-2013) .\end{array}$ & & \\
\hline
\end{tabular}

Table 6. Surveyed high-water mark elevations and hydraulicmodel elevations from the flood of June 1972, Tropical Storm Agnes, Susquehanna River near Harrisburg, Pennsylvania.

[NAVD 88, North American Vertical Datum of 1988; ft, feet]

\begin{tabular}{cccc}
\hline $\begin{array}{c}\text { River } \\
\text { mile }\end{array}$ & $\begin{array}{c}\text { High-water mark } \\
\text { elevation } \\
\text { (ft above NAVD 88) }\end{array}$ & $\begin{array}{c}\text { Modeled water- } \\
\text { surface elevation } \\
\text { (ft above NAVD 88) }\end{array}$ & $\begin{array}{c}\text { Elevation } \\
\text { difference } \\
\text { (ft) }\end{array}$ \\
\hline 83.47 & 359.3 & 360.0 & +0.7 \\
\hline 77.91 & 337.3 & 337.2 & -0.1 \\
\hline 75.13 & 331.4 & 330.5 & -0.9 \\
\hline 74.57 & 330.3 & 329.2 & -1.1 \\
\hline 71.14 & 325.9 & 326.3 & +0.4 \\
\hline 70.01 & 325.9 & 325.7 & -0.2 \\
\hline 69.67 & 325.2 & 324.7 & -0.5 \\
\hline 69.33 & 323.4 & 323.4 & 0.0 \\
\hline 168.77 & 321.9 & 321.3 & -0.6 \\
\hline 67.58 & 317.9 & 317.7 & -0.2 \\
\hline 66.80 & 316.1 & 316.6 & +0.5 \\
\hline 65.43 & 313.5 & 312.0 & -1.5 \\
\hline
\end{tabular}

${ }^{1}$ Approximate location of U.S. Geological Survey streamgage 01570500 (1928-1975)

Table 7. Water-surface elevations at U.S. Geological Survey streamgage 01570500 and modeled water-surface elevations associated with annual maximum streamflows, Susquehanna River at Harrisburg, Pennsylvania, water years ${ }^{1}$ 1996-2010.

[USGS, U.S. Geological Survey; NAVD 88, North Ameri can Vertical Datum of 1988; ft²/s, cubic feet per second; ft, feet]

\begin{tabular}{|c|c|c|c|c|}
\hline $\begin{array}{c}\text { Water } \\
\text { year }\end{array}$ & $\begin{array}{c}\text { USGS } 01570500 \\
\text { peak flow } \\
\left(\mathrm{ft}^{3} / \mathrm{s}\right)\end{array}$ & $\begin{array}{c}\text { USGS } 01570500 \\
\text { water-surface elevation } \\
\text { (ft above NAVD 88) }\end{array}$ & $\begin{array}{l}\text { HEC-RAS modeled } \\
\text { water-surface elevation } \\
\text { (ft above NAVD 88) }\end{array}$ & $\begin{array}{l}\text { Elevation } \\
\text { difference } \\
\text { (ft) }\end{array}$ \\
\hline 1996 & 568,000 & 314.0 & 313.9 & -0.1 \\
\hline 1997 & 261,000 & 304.5 & 304.6 & +0.1 \\
\hline 1998 & 316,000 & 306.6 & 306.6 & 0.0 \\
\hline 1999 & 234,000 & 303.5 & 303.5 & 0.0 \\
\hline 2000 & 214,000 & 302.6 & 302.7 & +0.1 \\
\hline 2001 & 151,000 & 299.9 & 299.8 & -0.1 \\
\hline 2002 & 194,000 & 301.8 & 301.8 & 0.0 \\
\hline 2003 & 272,000 & 304.9 & 305.0 & +0.1 \\
\hline 2004 & 557,000 & 313.7 & 313.6 & -0.1 \\
\hline 2005 & 360,000 & 308.2 & 308.1 & -0.1 \\
\hline 2006 & 383,000 & 309.0 & 308.8 & -0.2 \\
\hline 2007 & 239,000 & 303.7 & 303.7 & 0.0 \\
\hline 2008 & 320,000 & 306.7 & 306.7 & 0.0 \\
\hline 2009 & 142,000 & 299.5 & 299.3 & -0.2 \\
\hline 2010 & 303,000 & 306.1 & 306.1 & 0.0 \\
\hline
\end{tabular}

${ }^{1}$ Water year is defined as the 12-month period October 1, for any given year through September 30, of the following year. The water year is designated by the calendar year in which it ends and which includes 9 of the 12 months. Thus, the year ending September 30, 1999, is called the "1999" water year. 
Table 8. Water-surface elevations at U.S. Geological Survey streamgage 01570500 used as calibration targets and modeled watersurface elevations, Susquehanna River at Harrisburg, Pennsylvania.

[Rating number is 19.0. USGS, U.S. Geological Survey; NWS, National Weather Service; ft, feet; NAVD 88, North American Vertical Datum of 1988; ft³/s, cubic feet per second; --, not applicable]

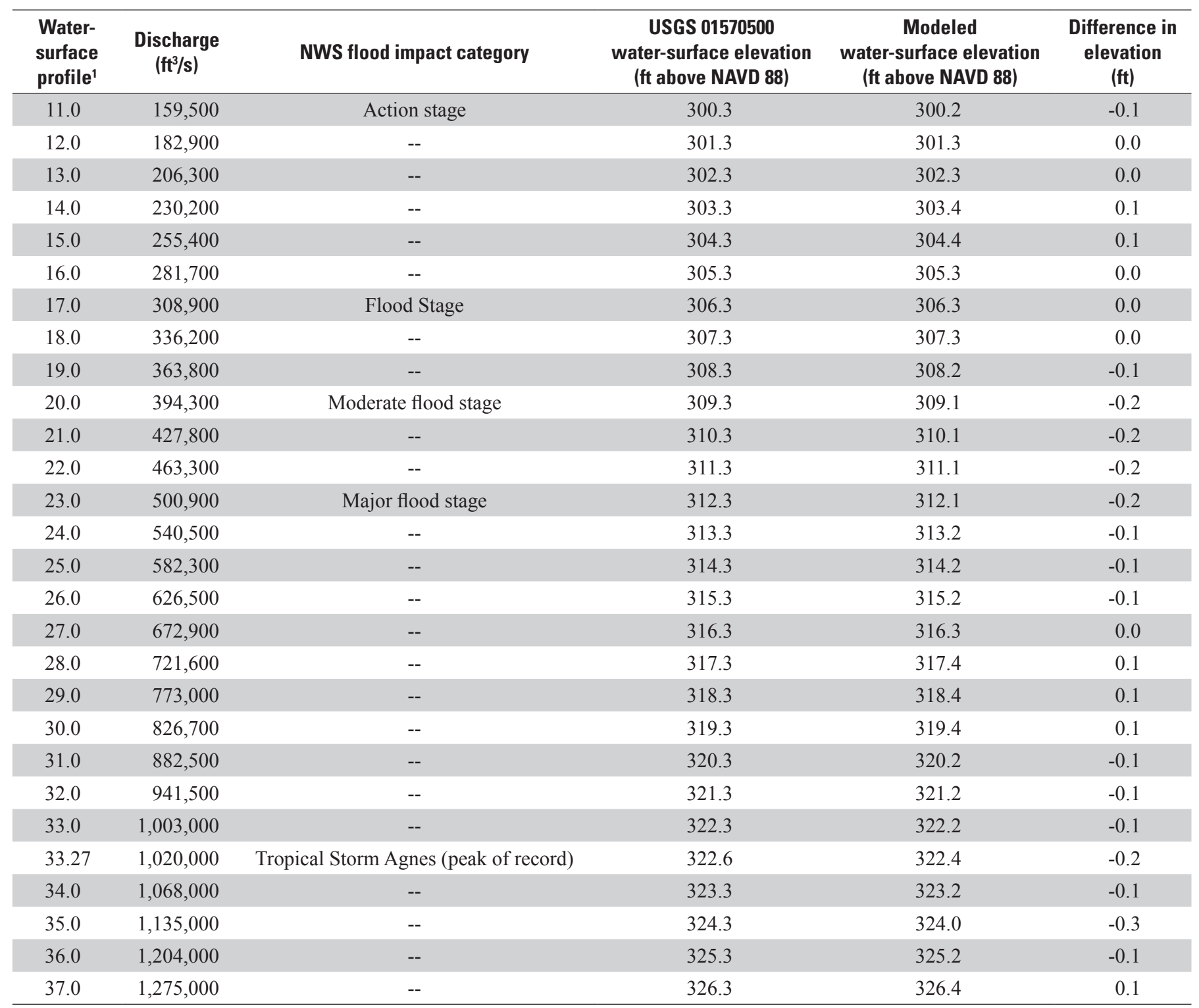

${ }^{1}$ Water-surface profiles are associated with stage, referenced to the gage datum of the U.S. Geological Survey streamgage 01570500 at its current (2013) location on City Island, Harrisburg, Pennsylvania. 
which represents the peak of record stage associated with Tropical Storm Agnes. Within the GIS environment, the next step was to create water-surface triangulated irregular networks (TINs) for each of the 28 modeled flood profiles. The TIN was created on the basis of the water-surface elevation at each modeled HEC-RAS cross section and without consideration of the bare-earth DEM. The next step was to delineate a flood plain for each water-surface TIN. To accomplish this, a flood plain polygon was created on the basis of the intersection of the water-surface TIN with the bare-earth DEM. The water-surface TIN was subsequently converted to a grid and compared to the bare-earth DEM. A depth grid was then created with values whereby the water-surface grid was higher than the bare-earth DEM and ultimately was converted into a flood plain polygon. This process resulted in the development of 28 flood plain polygons and depth grids for the main stem Susquehanna River study reach.

Backwater flooding occurred in the following four descriptive areas and was mapped independently of the main stem Susquehanna River: (1) the area along the Paxton Creek from its confluence with the Susquehanna River to the Harrisburg Area Community College; (2) the area behind the Capital City Airport, which is partially along the Yellow Breeches Creek tributary; (3) the area behind the Harrisburg International Airport State Route 230; and (4) the area along the Swatara Creek tributary from its confluence with the Susquehanna River continuing upstream to a point approximately 2,000 ft south of Interstate 76 . Water-surface elevations consistent with the point on the main stem Susquehanna River that was generating the backwater elevation were mapped using a process similar to the HEC-GeoRAS post-processing routines. During this mapping process, the backwater elevations were rendered as water-surface TINs, which were intersected with the bare-earth DEM to generate both depth grids and flood plain polygons. At this point in the post-processing, all depth grids and bare-earth DEM data within the backwater areas were redefined from a 3.2-ft horizontal ground resolution to a 5-ft horizontal ground resolution in order to accommodate computing times, transfer of data, and legacy mapping software. Once the four backwater areas were mapped, they were merged with the main-stem Susquehanna River flood areas (depth grids and the flood plain polygons). On the basis of main-stem model results, the levee system (in the vicinity of the Harrisburg International Airport) is overtopped at a stage of $36 \mathrm{ft}$; however, taking into consideration the backwater analysis for this area, inundation occurs behind the levee at a stage of $35 \mathrm{ft}$.

Prior to finalizing the data, the depth grids and flood plain polygons were reviewed and edited. The review and editing process consisted of (1) general smoothing and clean-up, (2) removal of any disconnected water bodies, and (3) bridge clips. Step 1 involved editing the maps including, but not limited to, smoothing the flood plain boundary to remove any unnatural anomalies generated by the mapping software and removing any disconnected parts of the flood plain that were too small to see at the recommended map scale. Step 2 involved checking hydraulically disconnected wet areas. If there was evidence that a wet disconnected pond was hydraulically connected (that is, an underground pipe connected the main stem Susquehanna River flood water to the disconnected pond), then no action was taken. If there was no evidence of a hydraulic connection, the disconnected pond was removed. Step 3 involved making the depth grids and flood plain polygons as accurate as possible by clipping bridges, if they were still usable during a flood event. Clipping a bridge means it is not shown as flooded and will remain usable. For the bridges on the Susquehanna River, a bridge was clipped (and shown as being usable) as long as the lowest part of the bridge was not affected by water. Once the lowest part of the bridge was affected, all subsequent and higher elevation water-surface profiles would not be clipped. For the non-main stem bridges, if the road-surface elevation of the bridge was not flooded, the bridge was clipped and shown to be usable for that flood profile. Once the lowest road-surface elevation associated with a bridge was affected by water, all subsequent and higher watersurface flood profiles would not be clipped. Once the mapping and depth grids were finalized, the layers went through a final review by the cooperating partners.

\section{Susquehanna River at Harrisburg, Pennsylvania, Flood-Inundation Maps on the Internet}

The flood-inundation maps from this study depict the estimated areal extent and depth of flooding corresponding to selected water levels (stages) at the USGS streamgage 01570500, Susquehanna River at Harrisburg, Pa. The maps can be accessed through various Web-mapping applications and are available in commonly used electronic file formats.

A USGS Flood Inundation Mapping Science internet portal has been established to provide estimated flood-inundation information to the public. The Web portal URL is http://water. usgs.gov/osw/flood_inundation/. From this portal, the USGS Flood Inundation Mapper Web site can be accessed. Figure 4 is a sample screen capture from this Web site depicting inundated areas within the study reach associated with a stage of 37 feet at the USGS streamgage, Susquehanna River at Harrisburg, Pa. Each stream reach displayed on the Web site contains links to NWISWeb (National Water Information System Web site, http://waterdata.usgs.gov) graphs of the current stage and streamflow at the USGS streamgage to which the inundation maps are referenced. The maps are also available from the NWS AHPS site (http://water.weather.gov) where the user can obtain applicable information on forecasted peak stage. Additionally, the maps are available from the SRBC Susquehanna Inundation Map Viewer (SIMV) Web site (http:// maps.srbc.net/simv/).

\section{Disclaimer for Flood-Inundation Maps}

Inundated areas shown are not intended for use in navigation, regulatory, permitting, or other legal purposes. The 


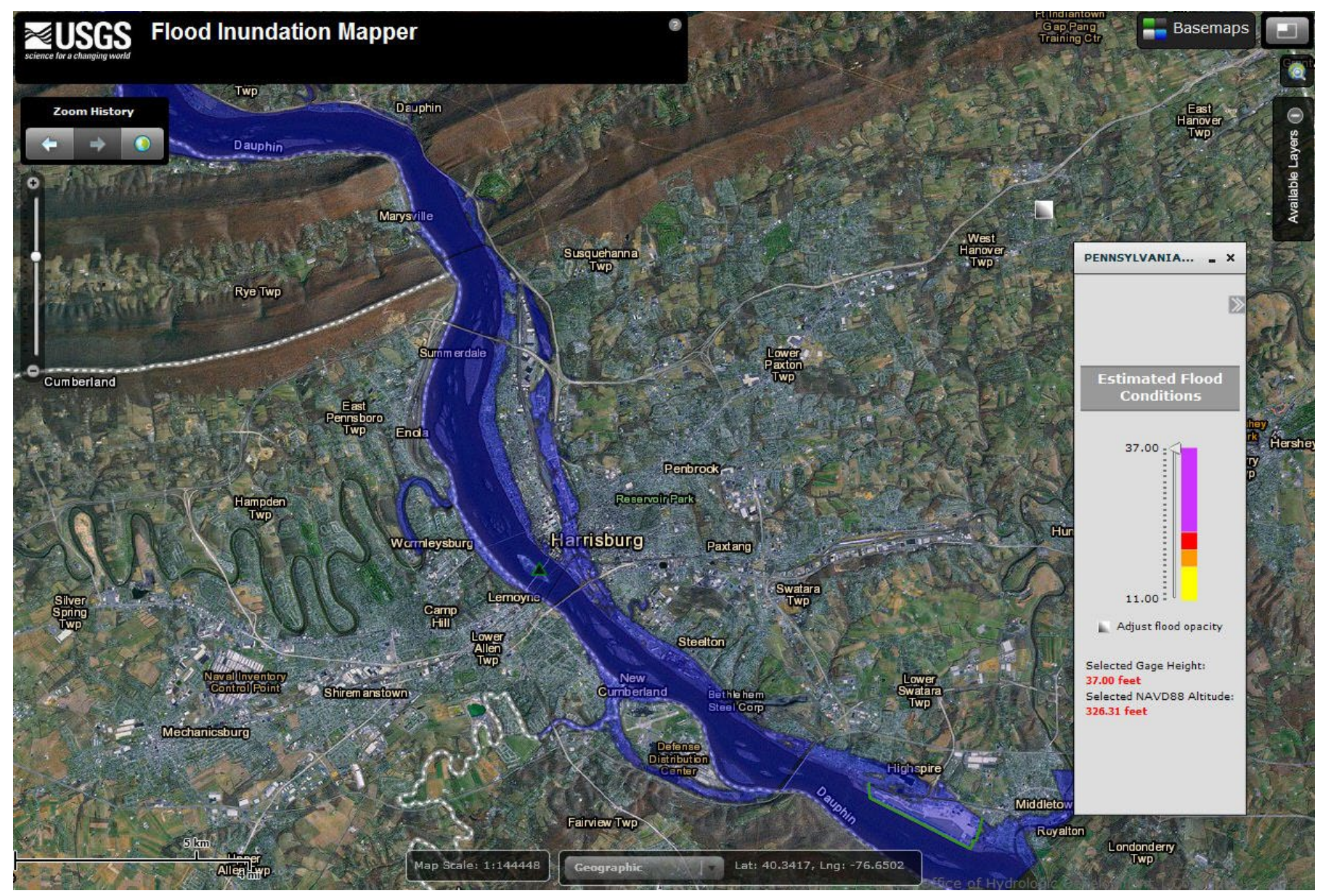

Figure 4. The U.S. Geological Survey Flood Inundation Mapper web site depicting inundated areas within the study reach associated with a stage of 37 feet at the U.S. Geological Survey streamgage 01570500, Susquehanna River at Harrisburg, Pennsylvania.

members of the Pennsylvania Silver Jackets team, including the USACE, NWS, SRBC, USGS, and The Harrisburg Authority, provide these maps "as is" for a quick reference, emergency planning tool but assume no legal liability or responsibility resulting from the use of this information.

\section{Uncertainty and Limitations Regarding Use of Flood-Inundation Maps}

Although the flood-inundation maps represent the boundaries of inundated areas with a distinct line, some uncertainty is associated with these maps. The flood boundaries shown were estimated on the basis of water stages/flows at USGS streamgage 01570500 . Water-surface elevations along the stream reaches were estimated by using steady-state hydraulic modeling, assuming unobstructed flow, and using discharges and hydrologic conditions anticipated at the streamgage. The hydraulic model reflects the land-cover characteristics and any bridge, dam, levee, or other hydraulic structures present as of the date of the published map. Unique meteorological factors (timing and distribution of precipitation) may cause actual discharges along the modeled reach to vary from those assumed during a flood and lead to deviations in the water-surface elevations and inundation boundaries shown. Additional areas may be flooded as a result of unanticipated backwater from major tributaries along the main stem or localized debris or ice jams, which can be a common occurrence during floods in the winter months. The flood-inundation boundaries depicted on these maps are based on DEMs of varying resolution. Additional uncertainties and limitations pertinent to this study are described elsewhere in this report.

The series of flood-inundation maps may be used in conjunction with NWS river forecasts that may have additional uncertainties inherent or factored into NWS forecast procedures. The NWS uses forecast models to estimate the quantity and timing of water flowing through selected stream reaches in the United States. These forecast models (1) estimate the amount of runoff generated by a precipitation or snowmelt event, (2) simulate the movement of floodwater as it proceeds downstream, and (3) predict the flow and stage (and watersurface elevation) for the stream at a given location (AHPS 
forecast point) throughout the forecast period (every 6 hours and 3 to 5 days out in many locations). For more information on AHPS forecasts, please see http://water.weather.gov/ahps/ pcpn_and_river_forecasting.pdf.

\section{Estimating Potential Losses Due to Flooding}

The static flood-inundation maps provide information relative to the depth and areal extent of flooding. These data can be incorporated into a methodology that has been developed by FEMA (2013a) to estimate the potential losses associated with the inundated areas as defined by the maps. This methodology involves the application of Hazus Multi-Hazard (Hazus-MH) software (Federal Emergency Management Agency, 2013b). Government planners, GIS specialists, and emergency managers use Hazus-MH to determine losses and the most beneficial mitigation approaches to take to minimize them (Federal Emergency Management Agency, 2013a).

As presented by Hearn and others (2013), Hazus-MH analyses are categorized according to the spatial resolution of the input data and the equations (loss functions) used in calculating loss and damage extents. A Level 1 estimate of flood loss can be performed using the national databases and analysis parameters included in the Hazus-MH software. A more accurate Level 2 estimate is produced by using more accurate maps of flood extent and (or) replacing the default asset inventories with more detailed local inventories of buildings, essential facilities, and other structures. The most accurate Level 3 estimates include all the improvements of a Level 2 estimate together with expert input from hydrologists or engineers to revise the analysis parameters (Federal Emergency Management Agency, 2013c).

Although Hazus-MH is able to generate reliable assessments of flood risk, its usefulness is limited because it can be run only on a workstation by a trained operator and analyses are not adapted for convenient delivery over the Internet (Hearn and others, 2013). In 2010, the USGS and FEMA began an effort to provide a solution to this problem by integrating Hazus-MH flood risk analyses with the USGS produced flood-inundation maps and make these data available on the Web (Hearn, and others, 2013). To this end, a Hazus-MH Level 1 analysis was performed for each of the 28 flood-inundation maps associated with the USGS streamgage 01570500, Susquehanna River at Harrisburg, Pa. Information relative to the functionality of the Hazus-MH as it relates specifically to the USGS flood-inundation map portal can be accessed online at http://water.usgs.gov/osw/flood_inundation/ toolbox/hazus.html.

\section{Relevance and Benefits of the Flood-Inundation Mapping}

Understanding and communicating flood risk are paramount to mitigating flood risk. The developed flood-inundation maps provide the expected extent of flooding relative to selected stages or flows at the streamgage, as well as associated depth of flooding. The mapping tools provide local officials, emergency managers, and the general public Web access to the mapped information. During times of flooding or predicted flooding, these data may be used by emergency managers for actions related to evacuation, identification of potential road-closure points for emergency vehicles, and the shutting down of power grids. The general public will have access to the maps and can make informed decisions about threats to life and property on the basis of the NWS forecast. Specifically, this information gives the public the opportunity to elevate valuables, move vehicles, prepare for evacuations and take other precautions to reduce flood damage.

This mapping effort covers about 20 communities adjacent to the Susquehanna River. A few communities have indicated they will revise their emergency action plans to include the use of these flood-inundation maps to assist with decision making prior to and during flood events. If the record peak flood (Tropical Storm Agnes) were to occur again, more than 7,000 land parcels would experience some degree of inundation. Structures located on those parcels would be inundated. Flood-inundation mapping will provide critical information that is necessary for residents and business owners to make sound decisions that could ultimately reduce flood damages and National Flood Insurance Program flood insurance claims.

\section{Community Outreach and Education}

Local outreach began in 2012 with a stakeholders meeting in Harrisburg to introduce the mapping study and garner feedback on the accuracy of the maps depicting flood inundation during Tropical Storms Agnes and Lee. Additionally, a Harrisburg Flood-Inundation Map exhibit was created for the annual Pennsylvania Farm Show in Harrisburg, Pa., January $5-12,2013$. The exhibit was part of the NWS booth. Estimated attendance at this event was 585,000 (Pennsylvania Department of Agriculture, press release, January 15, 2013).

A public information brochure and "Know Your Flood Elevation" magnet were mailed to all residents and businesses in the identified flood inundation zone in August 2013. The brochure included instructions relative to viewing the maps online, flood safety rules, and points of contact for additional information. The magnet was designed to promote public awareness of the local river stage that directly affects them, as well as provide information regarding the flood-inundation maps.

In the spring of 2013, Pennsylvania Silver Jacket team members also presented the maps at local municipal planning meetings where the target audience was composed primarily of county GIS officials and emergency managers. A presentation describing the study, including how to use and access the maps, was made to the Tri-County Regional Planning Commission in July 2013.

Outreach also includes a media campaign. The goals are to have a newspaper article printed in the local Harrisburg 
newspaper, The Patriot News, to have the NWS present a segment on the Pennsylvania State University television show, Weather World, and to have representatives from the SRBC and NWS talk with local TV weathercasters.

\section{Summary}

Digital flood-inundation maps for an approximately 25-mile reach of the Susquehanna River near Harrisburg, Pennsylvania, beginning just downstream from the confluence with the Juniata River and extending downstream to a location just below the confluence with Swatara Creek, were developed by members of the Pennsylvania Silver Jackets team, including the U.S. Army Corps of Engineers, National Weather Service (NWS), Susquehanna River Basin Commission (SRBC), U.S. Geological Survey (USGS), and The Harrisburg Authority. The inundation maps, which can be accessed through various Web-mapping applications, depict estimates of the areal extent and depth of flooding corresponding to selected water levels (stages) at the USGS streamgage 01570500, Susquehanna River at Harrisburg, Pa. Near realtime river stage conditions at the streamgage may be obtained on the internet from the USGS National Water Information System (http://waterdata.usgs.gov/). A USGS Flood Inundation Mapping Science internet portal has been established to provide estimated flood-inundation information to the public (http://water.usgs.gov/osw/flood_inundation/). In addition, the inundation maps and streamgage data have been provided to the NWS for incorporation into their Advanced Hydrologic Prediction Service (AHPS) Web site (http://water.weather. gov/). Forecasted peak-stage information available at the NWS AHPS Web site may be used in conjunction with the maps developed in this study to show predicted areas of flood inundation. The inundation maps can also be accessed through the SRBC Susquehanna Inundation Map Viewer (SIMV) (http:// maps.srbc.net/simv/).

Flood profiles were computed for the stream reach by means of a one-dimensional step-backwater model. The model was calibrated using the most current stage-discharge relations at USGS streamgage 01570500 , documented high-water marks from floods occurring in 1936 and 1972 (Tropical Storm Agnes), and sensor data and high-water marks from floods associated with Tropical Storm Lee (September 7-12, 2011). The hydraulic model was then used to determine 28 water-surface profiles for flood stages at 1 -foot intervals referenced to the streamgage datum and ranging from 11 feet ( $\mathrm{ft}$ ), which is associated with the NWS flood category Action Stage to $37 \mathrm{ft}$, which is the corresponding stage associated with 125 percent of the peak flow of record at USGS streamgage 01570500. The model was also used to compute a water-surface profile for Tropical Storm Agnes, which occurred on June 24,1972 , and is the peak-of-record flood event for this site at a stage of $33.27 \mathrm{ft}$ (at the current location of the streamgage on City Island). The simulated water-surface profiles were then combined with a geographic information system digital elevation model (derived from Light Detection and Ranging data having a 3.2-ft horizontal resolution) in order to delineate the area flooded at each water level.

The availability of these maps on various agency specific Web-based map viewers, along with information regarding current stage from USGS streamgages and stream stages used to support NWS forecasts and warnings, can provide emergency management personnel and residents with information that is critical for flood response activities, such as evacuations and road closures, as well as for post-flood recovery efforts.

\section{Selected References}

Esri, 2013, ArcGIS 10.0, accessed February 2013, at http:// www.esri.com/software/arcgis/.

Federal Emergency Management Agency, 2009a, Flood Insurance Study, Cumberland County, Pennsylvania: FIS number 42041CV001A, Volumes 1-2, [variously paged].

Federal Emergency Management Agency, 2009b, Flood Insurance Study, Perry County, Pennsylvania: FIS number 42099CV001A, Volumes 1-2, [variously paged].

Federal Emergency Management Agency, 2009c, Flood Insurance Study, York County, Pennsylvania: FIS number 42133CV001A, Volumes 1-6, [variously paged].

Federal Emergency Management Agency, 2012, Flood Insurance Study, Dauphin County, Pennsylvania: FIS number 42043CV001A, Volumes 1-3, [variously paged].

Federal Emergency Management Agency, 2013a. The Federal Emergency Management Agency's (FEMA's) Methodology for Estimating Potential Losses from Disasters, accessed July 1, 2013, at http://www.fema.gov/hazus.

Federal Emergency Management Agency, 2013b, Hazus Software: Federal Emergency Management Agency, accessed July 1, 2013, at http://www.fema.gov/hazus-software.

Federal Emergency Management Agency, 2013c. HAZUSMulti Hazard Analysis Levels. accessed July 1, 2013, at http://fema.gov/hazus/hazus-multi-hazard-analysis-levels.

Hearn, P.P., Longenecker, H.E., Aguinaldo, J.J., et al.: Delivering integrated HAZUS-MH flood loss analyses and flood inundation maps over the Web: Journal of Emergency Management 2013, 11(4), p. 293-302.

National Oceanic and Atmospheric Administration (NOAA), 2011, Partnered guidelines for the development of advanced hydrologic prediction service flood inundation mapping, September 2011, accessed October 31, 2013, at http://water. weather.gov/ahps/NOAA_AHPS_Guidelines_Final_2011_ v3.pdf. 
Page, L.V., and Shaw, L.C., 1973, Floods of June 1972 in the Harrisburg area, Pennsylvania: U.S. Geological Survey Hydrologic Investigations Atlas HA-530, 1 sheet.

PAMAP, 2006, PAMAP Program $3.2 \mathrm{ft}$ digital elevation model of Pennsylvania, accessed April 8, 2013, at $h t t p: / / w w w . p a s d a . p s u . e d u / u c i / M e t a d a t a D i s p l a y$. asp $x$ ?entry $=P A S D A \&$ file $=P A M A P \_D E M$. $x \mathrm{ml} \&$ dataset $=1247$.

U.S. Army Corps of Engineers, Baltimore District, March 1974, Floodplain Delineation, Susquehanna River Basin, Flood Hydrology Study — Tropical Storm Agnes: U.S. Army Corps of Engineers, $55 \mathrm{p}$.

U.S. Army Corps of Engineers, 2009, HEC-GeoRAS, GIS tools for support of HEC-RAS using ArcGIS, User's Manual, version 4.2: U.S. Army Corps of Engineers, [variously paged].

U.S. Army Corps of Engineers, 2010, HEC-RAS river analysis system, Hydraulic reference manual, version 4.1: U.S. Army Corps of Engineers, [variously paged].

U.S. Bureau of Census, 2010 state population finder, accessed March 3, 2013, at http://www.census.gov/ popfinder $/ ? f=42: 4204332800$.

Whitehead, M.T., and Ostheimer, C.J., 2009, Development of a flood-warning system and flood-inundation mapping for the Blanchard River in Findlay, Ohio: U.S. Geological Survey Scientific Investigations Report 2008-5234, 9 p. 

For additional information:

Director

U.S. Geological Survey

215 Limekiln Road

New Cumberland, PA 17070

http://pa.water.usgs.gov/ 
